\title{
Effects of by-product feed-based silage on feeding, rumination, and excretion in growing Hanwoo heifers
}

\author{
Young-II Kim, Sang Moo Lee, Youn Hee Lee, Myeon Lee, Do Young Choi and Wan Sup Kwak*
}

\begin{abstract}
This study investigated the effects of feeding by-product feed (BF)-based silage on the behavior of growing Hanwoo heifers. Twelve Hanwoo heifers (13.2 months-old, $315 \mathrm{~kg}$ body weight; four heifers per pen) were assigned to three diets: a rice straw (RS) diet (concentrate mix and free access to RS), a RS and BF-based silage (RSBFS) diet (concentrate mix and free access to RS and BF-based silage), and a BF-based silage (BFS) diet (concentrate mix and free access to BF-based silage). Behavior was recorded for 5 days using camcorders. Compared to the RS group, the BFS group showed $21.7 \%$ higher dry matter intake, shorter feeding, rumination, and chewing times, as well as longer resting time $(p<0.05)$. Although all groups exhibited similar drinking, urination, and defecation frequencies, the BFS group exhibited higher feeding rates, rumination efficiency, and chewing efficiency than the RS group $(p<0.05)$. Compared to the BFS group, the RSBFS group showed higher peNDF 8.0 intake $(15.2 \%$ vs. $25.0 \%$ dry matter intake), longer feeding and sitting times, lower defecation frequency $(p<0.05)$, and similar rumination efficiency. In conclusion, complete replacement of conventional RS with BF-based silage reduced rumination and chewing activity in growing Hanwoo heifers, and BF-based silage feeding with large-particle straw is an effective approach in improving heifer behavior.
\end{abstract}

Keywords: Spent mushroom substrate, By-product feed, Rumination, Behavior, Hanwoo heifer

\section{Background}

Demand for increased development of cheap domestic by-product feed (BF)-based roughage has increased in proportion to higher imported roughage and hay prices. Feeding of growing beef cattle with high quality roughage is an effective method of well-marbled beef [1]. Specifically, beef steers fed high quality timothy hay [2,3], during the growing period show improved growth and meat quality, and replacement of low quality rice straw (RS) with proteinaceous timothy and alfalfa hay has been shown to increase body weight gain and produce wellmarbled beef $[4,5]$. However, as a limitation, the price of timothy hay is twice that of RS.

In our previous study [6], cheap and high quality BF-based roughage was successfully manufactured by ensiling spent mushroom substrate (SMS), recycled poultry bedding $(\mathrm{RPB})$, rice bran, minimal straw with

\footnotetext{
* Correspondence: wsk@kku.ac.kr

Division of Food Bioscience, College of Health and Medical Life Sciences, Konkuk University, Chung-Ju, Chung-Buk 380-701, Korea
}

added molasses, and highly cellulolytic microbes, which were isolated from the SMS [7]. The silage exhibited favorable ensiling characteristics as well as higher degradability of dry matter (DM) and crude protein (CP) compared to RS or ryegrass straw [6]. Substitution of conventional RS with BF-based silage, which has a physically effective neutral detergent fiber (peNDF) ${ }_{1.18}$ of approximately $35 \%$, did not significantly affect the rumination behavior of Hanwoo steers [8]. However, no information is yet available on the effects of BF-based silage on Hanwoo heifers.

A proper dietary level of peNDF is required to maintain the ruminal $\mathrm{pH}$ above 6.2. There are two types of peNDF, peNDF ${ }_{8.0}$ and $\mathrm{peNDF}_{1.18}$, and little information is available on which peNDF is more reliable for predicting rumination behavior in growing beef cattle.

This study was attempted to determine the effects of BF-based silage on feeding, rumination, resting, and excretion in growing Hanwoo heifers as well as the reliability of 
dietary peNDF ${ }_{8.0}$ and peNDF ${ }_{1.18}$ for predicting rumination behavior in growing beef cattle.

\section{Methods}

\section{Animals and treatments}

All animal care protocols were approved by the Konkuk University Institutional Animal Care and Use Committee. Twelve Hanwoo heifers with a mean age of 13.2 months and a mean body weight (BW) of $315 \pm 1 \mathrm{~kg}$ were allocated to three pens (four heifers per pen). The area of each pen was $48 \mathrm{~m}^{2}(4 \mathrm{~m} \times 12 \mathrm{~m})$. Animals were fed one of three diets: a RS diet (concentrate mix and free access to $\mathrm{RS}$ ), a RS and BF-based silage (RSBFS) diet (concentrate mix and free access to RS and BF-based silage), and a BF-based (BFS) silage diet (concentrate mix and free access to BF-based silage). Feed was supplied twice a day (07:00 and 18:00). All animals were fed $4.7 \mathrm{~kg} / \mathrm{d}$ concentrate mix (normal commercial formulated feed) on a restricted basis, $0.45 \mathrm{~kg} / \mathrm{d}$ alfalfa hay, with free access to fresh water. All heifers were acclimatized to their diets and housing for over 1 month before the experiment.

\section{Manufacturing BF-based silage}

Fresh SMS was collected from a local oyster mushroom (Pleurotus ostreatus) farm. The original mushroom substrate consisted of $70 \%$ sawdust, $15 \%$ rice bran, and $15 \%$ corncobs. BF-based silage was manufactured as described by [6]. SMS (50\%) was mixed with RPB (21\%), cut ryegrass straw (15\%), rice bran (10.8\%), molasses (2\%), bentonite $(0.6 \%)$, and a microbial additive $(0.6 \%)$, followed by ensilation for over 2 weeks in two layers of polyvinyl bags placed in a 1-ton capacity plastic bag. The chemical compositions of feeds are presented in Table 1. BF-based silage contained more $\mathrm{CP}$ and ether extract (EE) but less NDF and acid detergent fiber (ADF) than RS.

\begin{tabular}{|c|c|c|c|c|}
\hline Item & $\begin{array}{l}\text { Rice } \\
\text { straw }\end{array}$ & $\begin{array}{l}\text { BF-based } \\
\text { silage }^{1)}\end{array}$ & $\begin{array}{l}\text { Alfalfa } \\
\text { hay }\end{array}$ & $\begin{array}{l}\text { Concentrate } \\
\text { mix }\end{array}$ \\
\hline
\end{tabular}

$\%$ dry matter (DM) retained on sieves

$\begin{array}{cllll}\text { Above } 19.0 \mathrm{~mm} & 97.8 & 10.3 & 45.8 & 0.8 \\ \text { 8.0-19.0 mm } & 1.2 & 8.2 & 10.7 & 53.9 \\ 1.18-8.0 \mathrm{~mm} & 0.9 & 54.6 & 26.2 & 45.1 \\ \text { Below } 1.18 \mathrm{~mm} & 0.1 & 26.9 & 17.3 & 0.2 \\ \text { Pef }_{8.0} & 99.0 & 18.5 & 56.5 & 53.9 \\ \text { pef }_{1.18} & 99.9 & 73.1 & 82.7 & 39.4 \\ \text { peNDF }_{8.0} \text { \% of DM } & 71.2 & 9.4 & 27.7 & 17.6 \\ \text { peNDF }_{1.18} \text { \% of DM } & 71.8 & 37.0 & 40.6 & 12.9\end{array}$

${ }^{1)} \mathrm{BF}$-based silage was a by-product feed-based silage, which was composed of $50 \%$ spent mushroom substrate, $21 \%$ recycled poultry bedding, $15 \%$ ryegrass straw, $10.8 \%$ rice bran, $2 \%$ molasses, $0.6 \%$ bentonite, and $0.6 \%$ microbial culture, and was ensiled for over 2 weeks.

\section{Particle size determination}

Particle sizes of the experimental feeds were measured using a Penn State Particle Separator, according to Kononoff and Heinrichs [9]. The separator consisted of three sieves $(1.18,8$, and $19 \mathrm{~mm})$ that could separate feeds into four types by particle size. For the physical effectiveness factor (pef), the proportion of particles larger than $8 \mathrm{~mm}$ was considered to be pef 8.0 , according to Lammers et al. [10], and the proportion of particles larger than $1.18 \mathrm{~mm}$ was considered to be pef $_{1.18}$, according to Kononoff and Heinrichs [9]. The peNDF ${ }_{8.0}$ and peNDF $_{1.18}$ were calculated by multiplying the NDF percentage by pef $_{8.0}$ and pef $_{1.18}$, respectively. For calculation of the concentrate mix pef p.18 $_{1 .}$, the ratio of the corn flake portion to the other portions was determined. The pef values for the corn flake portion and the other concentrate mix pellets were 0.8 and 0.3 , respectively, according to Metens [11]. The particle sizes of RS, alfalfa hay, BF-based silage, and concentrate mix used in this experiment are presented in Table 1. Compared to RS, BF-based silage had much smaller particles and much lower pef and peNDF values.

\section{Behavioral observation methods and analysis}

Prior to the experiment, the animals were adapted to night lighting for 10 days. Three camcorders (SVR-450, Samsung, Korea) were installed outside of the pen edge, and data were recorded for $120 \mathrm{~h}$ at each of the three pens. Feeding, rumination, and resting times, together with frequencies of defecation and urination, were measured at 1-min intervals and recorded on plotting paper.

Feed intake was calculated by measuring the difference between the supplied and remaining amounts of feed, and the remaining ort was retrieved and measured before the next morning's feeding. Chewing time was calculated by summing feeding and rumination times, and feeding, rumination, and chewing efficiencies were calculated by dividing voluntary DM intake by the respective feeding, rumination, or chewing times.

\section{Chemical analysis}

Representative samples of the test feeds were collected and stored at $-20^{\circ} \mathrm{C}$ for later analysis. Immediately before the analysis, all samples were dried, ground, and passed through a 1-mm screen using a Sample mill (Cemotec, Tecator, Sweden). The DM was determined by drying the samples at $65^{\circ} \mathrm{C}$ for $48 \mathrm{~h}$ to constant weight. $\mathrm{CP}(\mathrm{N} \times 6.25)$ and $\mathrm{EE}$ contents were determined using AOAC [12] methods. Crude ash was determined by heating samples at $600^{\circ} \mathrm{C}$ for $3 \mathrm{~h}$. Ash-free NDF and ADF were determined according to Van Soest et al. [13]. Non-fibrous carbohydrate content was calculated as 100 - (NDF \% + CP \% + EE \% + crude ash \%). As shown in Table 2, CP content of BF-based silage was $12.0 \%$, 
Table 2 Chemical compositions of the feeds fed to growing Hanwoo heifers

\begin{tabular}{lllll}
\hline Item & $\begin{array}{l}\text { Rice } \\
\text { straw }\end{array}$ & $\begin{array}{l}\text { BF-based } \\
\text { silage }\end{array}$ & $\begin{array}{l}\text { Alfalfa } \\
\text { hay }\end{array}$ & $\begin{array}{l}\text { Concentrate } \\
\text { mix }\end{array}$ \\
\hline \%, DM basis & & & \\
Dry matter & 85.0 & 58.3 & 83.3 & 87.9 \\
Crude protein & 3.6 & 12.0 & 14.7 & 16.4 \\
Ether extract & 1.1 & 3.9 & 1.2 & 2.5 \\
Crude ash & 8.3 & 11.5 & 9.9 & 8.3 \\
Neutral detergent fiber & 71.9 & 50.6 & 49.1 & 32.7 \\
Acid detergent fiber & 42.5 & 38.9 & 36.9 & 19.5 \\
Non-fibrous & 15.1 & 17.1 & 25.1 & 40.1 \\
carbohydrate & & & &
\end{tabular}

${ }^{11} \mathrm{BF}$-based silage was a by-product feed-based silage, which was composed of $50 \%$ spent mushroom substrate, $21 \%$ recycled poultry bedding, $15 \%$ ryegrass straw, $10.8 \%$ rice bran, $2 \%$ molasses, $0.6 \%$ bentonite, and $0.6 \%$ microbial culture, and was ensiled for over 2 weeks.

which was 3.3-fold higher than that of RS, and the NDF of BF-based silage was $21.3 \%$ lower than that of RS.

\section{Statistical analysis}

Data were subjected to one-way analysis of variance (ANOVA) using the general linear model (GLM) procedure [14]. Comparisons of means between RS, RSBFS, and BFS treatments were made using Tukey's multiple range test [14], and significance was set at $\mathrm{p}<0.05$.

\section{Results and discussion \\ Daily feed intake}

Daily feed intake of DM, NDF, and peNDF is presented in Table 3. Upon feeding with concentrate mix and alfalfa hay in equal amounts, daily roughage intake per head was $0.15 \mathrm{~kg}$ higher in the RSBFS group and $1.42 \mathrm{~kg}$ higher in the BFS group compared to the RS group. This increased feed intake is partly attributed to the fact that BF-based silage particles were smaller than those of RS, and it is known that small particle size can increase feed intake $[15,16]$. Martz and Belyea [17] reported that small particle size stimulates rapid ruminal passage of digesta and increases feed DM intake. Kim et al. [18] also reported that RS with a small particle size increases feed intake, and Kononoff and Heinrichs [9] reported that feed DM intake increases linearly as feed particle size decreases. Other reasons for increased feed intake may be favorable palatability and/or high digestibility of BFbased silage [6].

NDF intake by the BFS group was $15 \%$ higher than that by the RS group. Feeding of the BFS group with BFbased silage resulted in increased feed NDF intake due to higher feed DM intake, although the NDF content of BF-based silage was $21.3 \%$ lower than that of RS. The proportion of NDF intake per DM intake was similar (40-42\%) between treatments. These levels fully satisfied
Table 3 Effects of feeding by-product feed-based silage on feed dry matter (DM) and neutral detergent fiber (NDF) intakes in growing Hanwoo heifers

\begin{tabular}{|c|c|c|c|}
\hline \multirow[t]{2}{*}{ Item } & \multicolumn{3}{|c|}{ Diet $^{1)}$ with } \\
\hline & $\mathrm{RS}$ & RSBFS & $\mathrm{BFS}^{2)}$ \\
\hline Feed DM intake, kg/d & 6.53 & 6.68 & 7.95 \\
\hline Concentrate mix & 4.70 & 4.70 & 4.70 \\
\hline Alfalfa hay & 0.45 & 0.45 & 0.45 \\
\hline Rice straw & 1.38 & 0.93 & - \\
\hline BF-based silage & - & 0.60 & 2.80 \\
\hline NDF intake, kg/d & 2.75 & 2.73 & 3.17 \\
\hline Concentrate mix & 1.54 & 1.54 & 1.54 \\
\hline Roughage & 1.21 & 1.19 & 1.64 \\
\hline$\%$ of DMl & 42.1 & 40.9 & 39.9 \\
\hline peNDF $_{8.0}$ intake, $\mathrm{kg} / \mathrm{d}$ & 1.93 & 1.67 & 1.22 \\
\hline$\%$ of DMl & 29.6 & 25.0 & 15.3 \\
\hline peNDF $_{1.18}$ intake, $\mathrm{kg} / \mathrm{d}$ & 1.78 & 1.68 & 1.82 \\
\hline$\%$ of DMl & 27.3 & 25.1 & 22.9 \\
\hline
\end{tabular}

${ }^{11}$ The three diets were as follows: RS (free access to rice straw); RSBFS (free access to rice straw and BF-based silage); and BFS (free access to BF-based silage).

${ }^{2)}$ BF-based silage (BFS) was a by-product feed-based silage, which was composed of $50 \%$ spent mushroom substrate, $21 \%$ recycled poultry bedding, $15 \%$ ryegrass straw, $10.8 \%$ rice bran, $2 \%$ molasses, $0.6 \%$ bentonite, and $0.6 \%$ microbial culture, and was ensiled for over 2 weeks.

the minimum criterion of $25 \%$ dietary NDF, which is recommended for maintenance of normal ruminal $\mathrm{pH}$ [19]. In general, rumination time increases as NDF content increases, which helps to maintain a normal ruminal pH [20,21].

Intake of peNDF 8.0 decreased by $13.9 \%$ in the RSBFS group and by $37.6 \%$ in the BFS group. The reduced peNDF $_{8.0}$ intake per DM intake in the BFS group was due to the large difference in pef $_{8.0}$ between RS and BFbased silage ( $99.0 \%$ vs. $18.5 \%$, respectively). The $15.3 \%$ peNDF $_{8.0}$ intake per DM intake was just above the minimal 15\% level for maintenance of ruminal $\mathrm{pH}$ above 6.0, as suggested by Beauchemin et al. [22] and Zebeli et al. [23]. In the RSBFS group, peNDF ${ }_{8.0}$ intake per DM intake was higher than that of the BFS group.

The peNDF ${ }_{1.18}$ intake per DM intake (23-25\%) decreased by $2-4 \%$ when hiefers were fed BF-based silage. It has been reported that peNDF ${ }_{1.18}$ intake per DM intake should be $30 \%$ [11] or $30-32 \%$ [24] for maintenance of ruminal $\mathrm{pH}$ above 6.2 , whereas it should be at least $22.3 \%$ to maintain ruminal $\mathrm{pH}$ above 6.0 [11]. In the present study, 23-25\% peNDF 1.18 intake per DM intake in the BF-based silage-fed groups was sufficient to maintain ruminal $\mathrm{pH}$ above 6.0 but insufficient to maintain ruminal $\mathrm{pH}$ above 6.2. Consequently, for prediction of rumination behavior, dietary peNDF ${ }_{8.0}$ intake seemed to be a more reliable index than dietary peNDF 1.18 intake 
during the rumen-developing period of growing cattle, as also reported by Zebeli et al. [25].

\section{Feeding, rumination, and resting}

The effects of BF-based silage on feeding, rumination, chewing, and resting are presented in Table 4. The feeding times for dietary DM and NDF were longest in the RS group and shortest in the BFS group $(\mathrm{p}<0.05)$. This phenomenon can be attributed to the smaller particle size of BF-based silage. Other studies also found that small particle size reduces time taken to eat [20,9]. BFbased silage feeding did not affect feeding time of dietary $\mathrm{peNDF}_{8.0}$, although it decreased $(\mathrm{p}<0.05)$ feeding time of dietary peNDF ${ }_{1.18}$ in the BFS group.

Rumination time per dietary intake of DM, NDF, or peNDF $_{1.18}$ was shorter in the BF-based silage groups than in the RS group $(\mathrm{p}<0.05)$, despite higher dietary DM and NDF intakes. Okine and Mathison [26] reported that

Table 4 Effects of by-product feed-based silage on feeding, rumination, chewing, and resting in growing Hanwoo heifers

\begin{tabular}{|c|c|c|c|c|c|}
\hline \multirow[t]{2}{*}{ Item } & \multicolumn{3}{|c|}{ Diet $^{1)}$ with } & \multirow[t]{2}{*}{ SE } & \multirow[t]{2}{*}{$p$-value } \\
\hline & $\overline{\mathrm{RS}}$ & RSBFS & $\mathrm{BFS}^{2)}$ & & \\
\hline & $\min / d$ & & & & \\
\hline Eating time & $289.0^{\mathrm{a}}$ & $230.8^{b}$ & $159.8^{c}$ & 17.6 & 0.0002 \\
\hline Per kg of DM & $44.3^{\mathrm{a}}$ & $34.6^{\mathrm{b}}$ & $20.1^{c}$ & 2.6 & 0.0001 \\
\hline Per kg of NDF & $105.2^{\mathrm{a}}$ & $84.6^{\mathrm{b}}$ & $50.3^{c}$ & 6.3 & 0.0001 \\
\hline Per kg of peNDF 8.0 & 149.2 & 138.3 & 131.4 & 10.9 & 0.2978 \\
\hline Per kg of peNDF 1.18 & $162.6^{a}$ & $137.7^{\mathrm{a}}$ & $87.6^{b}$ & 10.1 & 0.0001 \\
\hline Ruminating time & $458.3^{\mathrm{a}}$ & $282.0^{b}$ & $317.5^{b}$ & 26.0 & 0.0002 \\
\hline Per kg of DM & $70.2^{\mathrm{a}}$ & $42.2^{\mathrm{b}}$ & $39.9^{\mathrm{b}}$ & 3.7 & 0.0001 \\
\hline Per kg of NDF & $166.8^{a}$ & $103.4^{\mathrm{b}}$ & $100.0^{b}$ & 9.1 & 0.0001 \\
\hline Per kg of peNDF ${ }_{8.0}$ & $237.0^{\mathrm{a}}$ & $169.0^{\mathrm{b}}$ & $261.2^{\mathrm{a}}$ & 17.1 & 0.0012 \\
\hline Per kg of peNDF 1.18 & $257.9^{\mathrm{a}}$ & $168.3^{b}$ & $174.1^{b}$ & 14.9 & 0.0003 \\
\hline Chewing time $e^{3)}$ & $747.3^{\mathrm{a}}$ & $512.8^{\mathrm{b}}$ & $477.3^{b}$ & 31.7 & 0.0001 \\
\hline Per kg of DM & $114.5^{\mathrm{a}}$ & $76.8^{\mathrm{b}}$ & $60.0^{c}$ & 4.6 & 0.0001 \\
\hline Per kg of NDF & $271.9^{a}$ & $188.0^{\mathrm{b}}$ & $175.0^{\mathrm{b}}$ & 11.5 & 0.0001 \\
\hline Per kg of peNDF 8.0 & $386.5^{\mathrm{a}}$ & $307.2^{b}$ & $392.7^{\mathrm{a}}$ & 19.8 & 0.0033 \\
\hline Per kg of peNDF 1.18 & $420.5^{a}$ & $306.1^{b}$ & $261.7^{b}$ & 18.1 & 0.0001 \\
\hline Resting time & $692.8^{b}$ & $927.3^{a}$ & $962.8^{a}$ & 31.3 & 0.0001 \\
\hline Standing time & $791.8^{\mathrm{a}}$ & $504.8^{b}$ & $668.0^{\mathrm{a}}$ & 44.5 & 0.0004 \\
\hline Sitting time & $648.2^{b}$ & $935.2^{\mathrm{a}}$ & $772.0^{b}$ & 44.5 & 0.0004 \\
\hline
\end{tabular}

${ }^{1)}$ The three diets were as follows: RS (free access to rice straw); RSBFS (free access to rice straw and BF-based silage); and BFS (free access to BF-based silage).

${ }^{2)} \mathrm{BF}$-based silage (BFS) was a by-product feed-based silage, which was composed of $50 \%$ spent mushroom substrate, $21 \%$ recycled poultry bedding, $15 \%$ ryegrass straw, $10.8 \%$ rice bran, $2 \%$ molasses, $0.6 \%$ bentonite, and $0.6 \%$ microbial culture, and was ensiled for over 2 weeks.

${ }^{3)}$ Chewing time $=$ eating time + rumination time.

$a, b, c$ Means with different superscripts within the same row are significantly different $(p<0.05)$.
Table 5 Effects of feeding by-product feed-based silage on drinking, urination, and defecation in growing Hanwoo heifers

\begin{tabular}{llllll}
\hline Item & \multicolumn{2}{l}{ Diet $^{\mathbf{1})}$ with } & & SE & p-value \\
\cline { 2 - 5 } & RS & RSBFS & BFS $^{\mathbf{2}}$ & & \\
\hline Drinking frequency/d & 10.3 & 7.0 & 6.8 & 1.7 & 0.1153 \\
Urinating frequency/d & 4.5 & 4.3 & 5.3 & 1.2 & 0.6829 \\
Defecating frequency/d & $5.5^{\text {ab }}$ & $3.5^{\mathrm{b}}$ & $6.8^{\mathrm{a}}$ & 1.1 & 0.0309 \\
\hline
\end{tabular}

${ }^{1)}$ The three diets were as follows: RS (free access to rice straw); RSBFS (free access to rice straw and BF-based silage); and BFS (free access to BF-based silage).

${ }^{2)}$ BF-based silage (BFS) was a by-product feed-based silage, which was composed of $50 \%$ spent mushroom substrate, $21 \%$ recycled poultry bedding, $15 \%$ ryegrass straw, $10.8 \%$ rice bran, $2 \%$ molasses, $0.6 \%$ bentonite, and $0.6 \%$ microbial culture, and was ensiled for over 2 weeks.

$a, b, c$ Means with different superscripts within the same row are significantly different $(p<0.05)$.

dietary NDF intake increases with rumination time. However, in the present study, BF-based silage feeding increased dietary NDF intake while reducing rumination time by $38-39 \%$ mainly due to decreased peNDF $_{8.0}$ intake (up to $48 \%$ ), which otherwise stimulates rumination activity. In the present study, the rumination time of $317.5 \mathrm{~min} / \mathrm{d}$ in the BFS group is similar to the $322.5 \mathrm{~min} / \mathrm{d}$ rumination time previously reported in Hanwoo steers (mean BW of $500 \mathrm{~kg}$ ) fed a 40:60 ratio of RS and concentrate mix [27]. This level is also higher than the $245.8 \mathrm{~min} / \mathrm{d}$ rumination time of early fattening Hanwoo steers $(491 \mathrm{~kg} \mathrm{BW})$ fed $1.1 \mathrm{~kg}$ of RS (12\%) and $7.6 \mathrm{~kg}$ of concentrate mix (88\%) [28], whereas it is lower than the $451 \mathrm{~min} / \mathrm{d}$ rumination time of growing Hanwoo steers (357 kg BW) fed $2.7 \mathrm{~kg}$ of RS (33\%) and $5.3 \mathrm{~kg}$ of concentrate mix (67\%) [29].

The values for chewing time (feeding time plus rumination time) were highest in the RS group and lowest in the BFS group $(\mathrm{p}<0.05)$, and chewing time per dietary DM or NDF intake was also lowest in the BFS group

Table 6 Effects of feeding by-product feed-based silage on feeding rate, rumination efficiency, and chewing efficiency in growing Hanwoo heifers

\begin{tabular}{llllll}
\hline \multirow{2}{*}{ Item } & \multicolumn{2}{l}{ Diet $^{\mathbf{1})}$ with } & SE & p-value \\
\cline { 2 - 4 } & RS & RSBFS & BFS $^{2)}$ & & \\
\hline Eating rate $^{3)}$ & $1,365.8^{\mathrm{b}}$ & $1,751.6^{\mathrm{b}}$ & $3,016.6^{\mathrm{a}}$ & 167.1 & 0.0001 \\
Ruminating efficiency $^{4)}$ & $857.6^{\mathrm{b}}$ & $1,446.6^{\mathrm{a}}$ & $1,516.7^{\mathrm{a}}$ & 119.5 & 0.0007 \\
Chewing efficiency $^{5)}$ & $525.2^{\mathrm{c}}$ & $788.4^{\mathrm{b}}$ & $1,003.9^{\mathrm{a}}$ & 50.2 & 0.0001 \\
\hline
\end{tabular}

${ }^{1)}$ The three diets were as follows: RS (free access to rice straw); RSBFS (free access to rice straw and BF-based silage); and BFS (free access to BF-based silage).

${ }^{2)}$ BF-based silage (BFS) was a by-product feed-based silage, which was composed of $50 \%$ spent mushroom substrate, $21 \%$ recycled poultry bedding, $15 \%$ ryegrass straw, $10.8 \%$ rice bran, $2 \%$ molasses, $0.6 \%$ bentonite, and $0.6 \%$ microbial culture, and was ensiled for over 2 weeks.

${ }^{3)}$ Voluntary intake (DM g/d)/feeding time (h/d).

${ }^{4)}$ Voluntary intake (DM g/d)/rumination time (h/d).

${ }^{5)}$ Voluntary intake (DM g/d)/chewing time (h/d).

$a, b, c$ Means with different superscripts within the same row are significantly different $(p<0.05)$. 
$(p<0.05)$. Similarly, Mertens [11] reported that as feed intake increases, chewing time per DM intake decreases since the amount of time that animals are able to chew per day is limited. In addition, Beauchemin et al. [22] reported that as peNDF ${ }_{1.18}$ intake increases, chewing time per $\mathrm{kg}$ of peNDF $\mathrm{N}_{1.18}$ decreases, as partially confirmed in the present study. We found that $15.3 \%$ dietary intake of $\mathrm{peNDF}_{8.0}$ in the BFS group suppressed rumination and chewing activity.

BF-based silage feeding resulted in a longer resting time compared to RS $(\mathrm{p}<0.05)$. Standing and sitting times were similar between the RS and BFS groups, whereas the RSBFS group spent more time sitting compared to the BFS group $(\mathrm{p}<0.05)$.

\section{Drinking and excretion}

The effects of BF-based silage feeding on drinking and excretion are shown in Table 5. Complete replacement of RS with BF-based silage did not affect drinking, urination, or defecation frequency. The increased feed intake by heifers fed BF-based silage did not result in significant elevation of excretion frequency. Ryu et al. [30] reported that urination frequency varies with feed type and cattle age. In our study, the RSBFS group showed a significantly lower defecation frequency $(\mathrm{p}<0.05)$ than the BFS group.

\section{Feeding rate, rumination efficiency, and chewing efficiency}

The effects of BF-based silage on feeding rate, rumination efficiency, and chewing efficiency are presented in Table 6. The feeding rate was highest in the BFS group and lowest in the RS group $(\mathrm{p}<0.05)$. Kim et al. [18] stated that feeding rate increases when the length of feeding time is shortened, and Jeon et al. [31] found that the feeding rate is high when using roughage with a small particle size. In the present study, rumination efficiency was high in the BF-based silage groups $(\mathrm{p}<0.05)$. Lee et al. [29] reported that rumination efficiency varies with feed characteristics, animal age, and health status, and Balch [32] stated that rumination efficiency is a key factor in determining the physical characteristics of a feed.

Chewing efficiency was highest in the BFS group and lowest in the RS group $(\mathrm{p}<0.05)$. Woodford et al. [20] and Ryu et al. [29] found that crushed and chopped feed with a small particle size reduces feeding time compared with feeds in their original form. Considering this, the increased chewing efficiency in the BF-based silage groups can be attributed to increased feeding rate and decreased feeding time. Therefore, the increase in feed DM intake by BF-based silage feeding can also be explained by improved feeding and chewing efficiencies. In a study by Lee et al. [33], wet total mixed ration feeding in a restricted or ad libitum manner resulted in elevated feed intake, followed by increases in feeding, rumination, and chewing efficiencies. These phenomena can improve the ruminal environment for enhanced animal productivity.

In conclusion, compared to RS, ad libitum BF-based silage feeding resulted in higher feed DM and NDF intake, shorter feeding, rumination, and chewing times, longer resting times $(\mathrm{p}<0.05)$, as well as higher feeding, rumination, and chewing efficiencies $(\mathrm{p}<0.05)$. Both groups exhibited similar frequencies of defecation, urination, and drinking. Compared to only ad libitum BF-based silage feeding, RS and BF-based silage together resulted in higher peNDF$_{8.0}$ intake (15.2 vs. $25.0 \%$ of DMI, respectively), longer feeding and sitting times, lower defecation frequency $(\mathrm{p}<0.05)$, and a similar rumination efficiency.

\section{Conclusions}

Dietary peNDF 8.0 intake level was a better predictor of rumination behavior in growing Hanwoo heifers than dietary peNDF ${ }_{1.18}$ intake, and the complete replacement of conventional RS with BF-based silage depressed rumination activity. BF-based silage feeding with largesized particle straw is an effective way of improving the behavior pattern of growing Hanwoo heifers.

\section{Competing interests}

The authors declare that they have no competing interests.

\section{Authors' contributions}

YI carried out the behavioral observations and drafted the manuscript as the first author. SM made substantial contributions to the conception of the study and the experimental design. YH and M conducted the chemical analysis, and DY performed the statistical analysis. WS made substantial contributions to the study conception and design, and revised the manuscript as the corresponding author. All authors read and approved the final manuscript.

\section{Acknowledgements}

This study was carried out with the support of the "Cooperative Research Program for Agriculture Science and Technology Development (Project No. PJ009382012015)", the Rural Development Administration, Republic of Korea.

Received: 19 September 2014 Accepted: 21 December 2014 Published online: 27 January 2015

\section{References}

1. Sainz RD, De la Torre F, Oltjen JW. Compensatory growth and carcass quality in growth-restricted and refed beef steers. J Anim Sci. 1995;73:2971-9.

2. Matsumoto D: Fattening management program of black haired Hwawoo. In: Beef Cattle - Production and Veterinary Medicine System. Japanese Agricultural, Forestry and Fishery Culture Association. 1999:75-83.

3. Kim BK. Effects of feeding high quality roughage (timothy hay) during growing period on growth performance and carcass characteristics of Hanwoo steers. Korean J Food Sci Anim Resour. 2006;26:212-7.

4. Kim SI, Jung GG, Kim JY, Lee SW, Baek KH, Choi CB. Effect of feeding high quality hay on performance and physico-chemical characteristics of carcass of Hanwoo steers. Korean J Anim Sci Technol. 2007;49:783-800.

5. Oh YG, Nam IS, Choi CW, Baek KH, Kim JH, Kim DH, et al. Effects of different levels of $\mathrm{CP}$ intake on protein utilization and $\mathrm{N}$ excretion in varying growth stages of Hanwoo steers. Korean J Anim Sci Technol. 2007;49:369-78.

6. Kim Yl, Oh YK, Park KK, Kwak WS. Ensiling chracteristics and the in situ nutrient degradability of a by-product feed-based silage. Asian-Aust J Anim Sci. 2014;27:201-8. 
7. Kim YI, Jeong SH, Seok JS, Yang SY, Huh JW, Kwak WS. Isolation and identification of hydrolytic enzyme-producing bacteria from spent mushroom substrate. Korean J Anim Sci Technol. 2008;50:713-20.

8. Kim YI, Lee SM, Park KK, Kwak WS. Effect of feeding by-product feeds-based silage (Biosilage) on behavior pattern of growing Hanwoo steers. J Kor Grassl Forage Sci. 2013;33:290-7.

9. Kononoff PJ, Heinrichs AJ. The effect of reducing alfalfa haylage particle size on cows in early lactation. J Dairy Sci. 2003;86:1145-457.

10. Lammers BP, Buckmaster DR, Heinrichs AJ. A simple method for the analysis of particle size of forage and total mixed rations. J Dairy Sci. 1996;79:922-8.

11. Mertens DR. Creating a system for meeting the fiber requirements of dairy cows. J Dairy Sci. 1997:80:1463-81.

12. AOAC (Association of Official Analytical Chemists). Official methods of analysis. 17th ed. Association of Analytical Chemists: Washington DC, USA; 2000.

13. Van Soest PJ, Robertson JB, Lewis BA. Methods for dietary fiber, neutral detergent fiber, nonstarch polysaccharides in relation to animal nutrition. J Dairy Sci. 1991;74:3583-97.

14. Statistix7: User's manual. Analytical Software, Tallagassee, FL, USA; 2000.

15. Kato K, Kajima Y, Odashima M, Lee LS, Nam KT, Chiga H, et al. Feed passage and digestibility in Japanese deer and sheep. Research Report of Kawatabi Experimental Station. 1989;5:59-62.

16. Jeon BT, Moon SH, Kwon YJ, Kwak WS. Effect of supplementary level of fermented broiler litter on the dry matter intake, digestibility and nitrogen balance in female spotted deer (Cervus Nippon). Korean J Anim Sci. 2001;43:730-1.

17. Martz FA, Belyea RL. Role of particle size and forage quality in digestion and passage by cattle and sheep. J Dairy Sci. 1986;69:1996-2008.

18. Kim CM, Lee BS, Chung TY. Influence of cutting length of ammoniated barley straw on the eating and ruminating behavior of Korean native cattle. Korean J Anim Sci. 1994;36:487-93.

19. NRC. Nutrient requirements of dairy cattle. 7th ed. Washington, DC, USA: National Academy Press; 2001.

20. Woodford JA, Jorgensen NA, Barrington GP. Impact of dietary fiber and physical form on performance of lactating dairy cows. J Dairy Sci. 1986;69:1035-47.

21. Beauchemin KA, Buchanan S. Effects of dietary neutral fiber concentration and supplementary long hay on chewing activities and milk production of dairy cows. J Dairy Sci. 1989;72:2288-300.

22. Beauchemin KA, Yang WZ, Rode LM. Effects of particle size of alfalfa-based dairy cow diets on chewing activity, ruminal fermentation, and milk production. J Dairy Sci. 2003;86:630-43.

23. Zebeli Q, Tafaj M, Weber I, Dijkstra J, Steingass H, Drochner W. Effects of varying dietary forage particle size in two concentrate levels on chewing activity, ruminal mat characteristics and passage in dairy cows. J Dairy Sci. 2007;90:1929-42

24. Zebeli Q, Mansmann D, Steingass H, Ametaj BN. Balancing diets for physically effective fibre and ruminally degradable starch: a key to lower the risk of sub-acute rumen acidosis and improve productivity of dairy cattle. Livestock Sci. 2010;127:1-10.

25. Zebeli Q, Tafaj M, Steingass H, Metzler B, Drochner W. Effects of physically effective fiber on digestive processes and milk fat content in early lactating dairy cows fed total mixed rations. J Dairy Sci. 2006;89:651-68.

26. Okine EK, Mathison GW. Effects of feed intake on particle distribution, passage of digesta, and extent of digestion in the gastrointestinal tract of cattle. J Anim Sci. 1991;69:3435-45.

27. Lee WS, Lee BS, Lee SC, Lee SS, Lee SY, Lee DY, et al. Effects of rice straw and rice hull supplement on rumination and chewing behavior in Hanwoo steers. Kor J Anim Sci and Technol. 2004;46:49-54.

28. Lee SM, Kim YI, Kwak WS. Effect of by-product mixing silage feeding on the eating and ruminating behavior of Hanwoo steer. J Kor Grassl Forage Sci. 2010;30:159-68.

29. Lee SM, Hwang JH, Yoon YB, Kwak WS, Kim YI, Moon SH, et al. Effects of spent mushroom substrates addition on eating behavior of growing Hanwoo. J Kor Grassl Forage Sci. 2008;28:107-18.

30. Ryu YW, Ko YD, Lee SM. Effects of feeding rice straw silage made with apple pomace, sesame oil meal and cage layer excreta on growth rate, eating behavior and economical efficiency in Korean native cattle. Korean J Anim Sci. 1998;40:235-44.
31. Jeon BT, Park IH, Lee SM, Moon SH, Kim KH, Kim JS, et al. The effects of different fiber sources on chewing behavior of Korean native cattle. Korean J Anim Sci. 1997;39:383-90.

32. Balch CC. Proposal to use time spent chewing as an index of the extent to which diets for ruminants possess the physical property of fibrous characteristic of roughages. Br J Nutr. 1971;26:383-92.

33. Lee SM, Kim Yl, Oh YK, Kwak WS. Effects of feeding methods of total mixed ration on behavior patterns of growing Hanwoo steers. Asian-Aust J Anim Sci. 2010;23:1469-75.

\section{Submit your next manuscript to BioMed Central and take full advantage of:}

- Convenient online submission

- Thorough peer review

- No space constraints or color figure charges

- Immediate publication on acceptance

- Inclusion in PubMed, CAS, Scopus and Google Scholar

- Research which is freely available for redistribution 